\title{
Disentangling Subject and Anacoluthon NPs in Topic: A Cognitive Grammar and Gestalt Psychology based approach
}

\author{
Luis Filipe Lima e Silva ${ }^{1}$ \\ Ronaldo Rodrigues de Paula ${ }^{2}$
}

\begin{abstract}
In this paper we analyze NPs in Topic which can be either the subject of the verb in Comment, or autonomous items usually called anacolutha (LI; THOMPSON, 1976). It explores how these different NPs are mapped according to spontaneous speech data. Departing from Langacker's proposal (2001), in which the Topic and the subject act as trajectors of different scopes, it is argued that such a concept is adequate to the empirical data, since it allows the possibility of co-occurrence and intertwining of both categories in speech. In addition, we also investigated the difference in the cognitive processing of subject and anacoluthon NPs in Topic building upon the concepts of baseline and elaboration (LANGACKER, 2016). Through this framework, it is possible to conceive that the Topic-Comment is activated serially giving rise to the formation of structural layers in the cases that the NP in Topic is the subject of the verb in the Comment. Or it can be the result of a cumulative access via summation, if the NP is an anacoluthon. As the concepts of subject and Topic in the approach of Cognitive Grammar derive, in part, from the Gestalt psychology notions of Figure and Ground, the anacoluthon in Topic can be referred to as the Figure and the illocutionary force of the Comment would be the Ground. The only difference in relation to the visual elements is that, since they displaces through the space axis, the Figure and the Ground can be inverted depending on where the focus of attention is turned. However, as the speech is unfolded along the time axis, reversion is not possible, in such a way that an Anacoluthon in Topic will always be the Figure and the Comment will always be the Ground. In addition, the dependency relation of the Figure regarding the Ground explains the reason for a Topic cannot occur without a Comment.
\end{abstract}

Keywords: Noun Phrase. Subject. Anacoluthon. Topic. Gestalt.

\section{Introduction}

This paper is part of a larger research project in speech syntax (cf. SILVA, 2012; 2020a, 2020b; MELLO; SILVA, 2015; SILVA; MELLO, 2016a, 2016b; 2017). The spontaneous speech is defined as the speech which is planned simultaneously as it is

\footnotetext{
${ }^{1}$ Graduou-se em Letras (habilitação em Linguística) pela Universidade Federal de Minas Gerais (2013), mestrado (2016) e doutorado (2020) em Estudos Linguísticos pela mesma instituição. Tem experiência na área de Linguística, com ênfase em Teoria e Análise Linguística, atuando principalmente nos seguintes temas: sintaxe, pragmática, gramaticalização e corpus de fala espontânea. É integrante do grupo de pesquisa InCognito Interfaces Linguagem, Cognição e Cultura. Minas Gerais, Brasil. E-mail: luisf.1397@gmail.com. ORCID iD: 0000-0003-0188-2861

${ }^{2}$ Doutor em Linguística Teórica e Descritiva da linha de pesquisa em sintaxe formal pelo Programa de PósGraduação em Estudos Linguísticos (Poslin) da Faculdade de Letras (Fale) da Universidade Federal de Minas Gerais (UFMG). Graduou-se em Letras pela Universidade Federal de São João Del-Rei (UFSJ) em 2013. Faz parte do grupo de pesquisa "Laboratório de Línguas Indígenas e Africanas". Minas Gerais, Brasil. E-mail: ronaldorodriguesdepaula@gmail.com. ORCID iD: https://orcid.org/0000-0002-3251-881.
} 


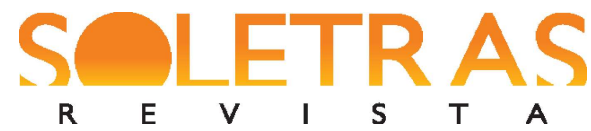

N. $41-2021.1$ - LUIS FILIPE LIMA E SILVA

RONALDO RODRIGUES DE PAULA

performed (MILLER; WEINERT, 1998). As a result of this dynamic process, there are some syntactic properties typically found in the spoken diamesia. It is important to mention that the spontaneous speech is parsed in tonal units determined by specific prosodic patterns (cf. t' HART et al. 1990). Such units of the prosodic level correspond to informational units in the pragmatic one. Therefore, the information structure of an utterance is clarified by prosodic patterns (BAUMANN, 2006; DePAPE et al. 2012; GUT \& PILLAI, 2014; HIMMELMANN, 2018). In this paper we focus on the NPs in Topic which can concomitantly be subjects of the following verb in the next informational unit and the ones that can be standalone items, that is, what is usually termed as anacolutha (LI; THOMPSON, 1976). The notions of Topic and subject portrayed in this paper were drawn from the Cognitive Grammar framework. Moreover, it is commonly accepted that Topic is performed with a specific prosodic pattern of a prefix type (t' HART et al. 1990). The following instances show both a NP subject and a NP anacoluthon realized as Topics ${ }^{3}$ respectively.

(1) a. *KIR: the $[/ 1]$ the penguins / ${ }^{\mathrm{TOP}}$ are numbered //COM

b. *COR: it was like / INT this one guy $/{ }^{\mathrm{TOP}}$ he gets this master //COM

In the example (1a), the NP the penguins is a Topic and also the subject of the Comment - the predicate are numbered. Inasmuch, in the example (1b), the Topic NP this one guy is an anacoluthon, or a standalone NP, once the subject of the sentence in the Comment segment is the pronoun $h e^{4}$. Since the framework of Cognitive Grammar is based on introspective data, an issue worth exploring is how the cognitive constitution of these different NPs is mapped according to empirical data. Or, in other words, how cognitively structured in regard to their syntactic and discursive patterns they are. Thereupon, it is relevant to research how the speech data unfolds in relation to their cognitive proprieties.

\footnotetext{
3 The examples were extracted from Santa Barbara Corpus of Spoken American English (DUBOIS et al. 20002005). The letters following the asterisk indicate the participant of the text. The simple bars indicate a nonterminal prosodic break, inasmuch the double bars indicate a terminal prosodic break. The symbol $[/ \mathrm{n}]$ indicate a retracting and the number of retracted words. TOP, COM and INT indicate the information units of Topic, Comment and Locutive Introducer, respectively.

${ }^{4}$ It is important to emphasize that we have not adopted in this paper the generative typology proposed by Ross (1967), in which this kind of clause as a case of left dislocation. We consider anacoluthon any NP in the Topic unit that does not hold the subject syntactic function. That is, an NP that does not establish a syntactic relation to the content in the Comment unit.
} 


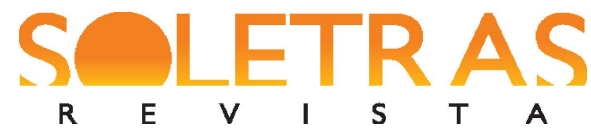

N. 41 - 2021.1 - LUIS FILIPE LIMA E SILVA

RONALDO RODRIGUES DE PAULA

Building upon Langacker (2001) and Kumashiro \& Langacker (2003) proposals, in which the Topic and the subject act as trajectors of distinct scopes, we argue that such a concept is suitable to empirical data, since it brings about the possibility of the co-occurrence and the intertwinement of both categories in speech. Besides that, based on the concepts of baseline and elaboration (LANGACKER, 2016), we will show the difference in cognitive processing of subject and anacoluthon NPs when they figure in the information unit of Topic.

It is necessary to clarify that the concepts of subject and Topic in the Cognitive Grammar approach derive from the Gestalt psychology's notions of Figure and Ground. We believe that it is crucial to verify how one of the items in consideration, more specifically speaking the anacoluthon NPs as Topics, relate to the notion of Figure and Ground using as our guideline the very source of those notions, that is, the Gestalt Psychology approach. Therefore, the objectives of this paper are, (i) To characterize subject and anacoluthon NPs from the viewpoint of empirical data, in order to lay out them cognitively, and (ii) to disentangle the properties of anacoluthon NPs according to the Gestalt perspective. In order to achieve these objectives, we analyzed Brazilian Portuguese and Spanish spontaneous speech data in which the pattern Topic-Comment was manifested. This paper is set up as follows; firstly, which we approach the notions of subject and anacoluthon NPs in Topic according to Cognitive Grammar is divided in two subsections; after that, we briefly discuss some relevant notions from Cognitive Grammar framework. We analyze subject and anacoluthon as trajectors of different levels. Subsequently, we approach the subject and anacoluthon NPs in Topic according to Gestalt Psychology. This section is also divided in two subsections; the first one, we explain some important concepts of Gestalt Psychology and in the second one, we view the spontaneous speech data according to those concepts. Finally, in the next subsection we leave you with our final remarks.

\section{Subject and Anacoluthon NPs in Topic according to Cognitive Grammar}

In this section, a brief overview of the notions of subject and Topic will be presented according to the framework of Cognitive Grammar (LANGACKER, 1987; 1991; 2008). In order to do so we will explore in the following sections how those concepts are viewed as 
trajectors of different scopes potentially seeking different landmarks. After these notions become settled, the close relationship between subjects and anacolutha in Topic will be more evident, if we consider an intertwinement of both scopes in spontaneous speech.

\section{Cognitive Grammar}

According to Langacker (1987), the three following perspectives are central to Cognitive Grammar:

1- Semantic structure is not universal; it is language-specific to a considerable degree. Further, semantic structure is based on conventional imagery and is characterized relative to knowledge structures.

2- Grammar (or syntax) does not constitute an autonomous formal level of representation. Instead, grammar is symbolic in nature, consisting in the conventional symbolization of semantic structure.

3- There is no meaningful distinction between grammar and lexicon. Lexicon, morphology, and syntax form a continuum of symbolic structures, which differ along various parameters but can be divided into separate components only arbitrarily. (LANGACKER, 1987, p. 3)

Cognitive Grammar recognizes the symbolic nature of language. Linguistic expressions are the association of semantic representation with a phonological realization. In this framework, language is viewed as part of human cognition, and hence, the postulation for a separate module just for the language faculty in the mind is not necessary. In that fashion, language could be derived from more general cognitive functions of the mind in broader psychological phenomena. Meaning, viewed as conceptualization, is what language is built upon and it is a cognitive phenomenon. The grammar is responsible to assemble the semantic content from basic meaningful parts, such as morphemes into larger and inherently symbolic meaningful units. Due to this conceptual nature, a prototype analyzes of the linguistic phenomena is considered preferable to the standard categorical judgments.

Building up from the essential understanding that linguistic units are abstracted from usage events, Langacker (2001) explores the intimacy relation of Cognitive Grammar and 
discourse patterns. He called Ground $(\mathrm{G})$ the speech event itself comprising the speaker, the hearer, their interaction and the immediate circumstances in which the interaction happens. The Current discourse space (CDS) is an abstract space built in the minds of the discourse participants consisting of the elements and relations constructed in the interaction at a given moment. Those are the cognitive domains that form the conceptual base for the meaning of the linguistic units. He proposed the following schematic conceptualization (LANGACKER, 2001, p. 145-146 adapted):

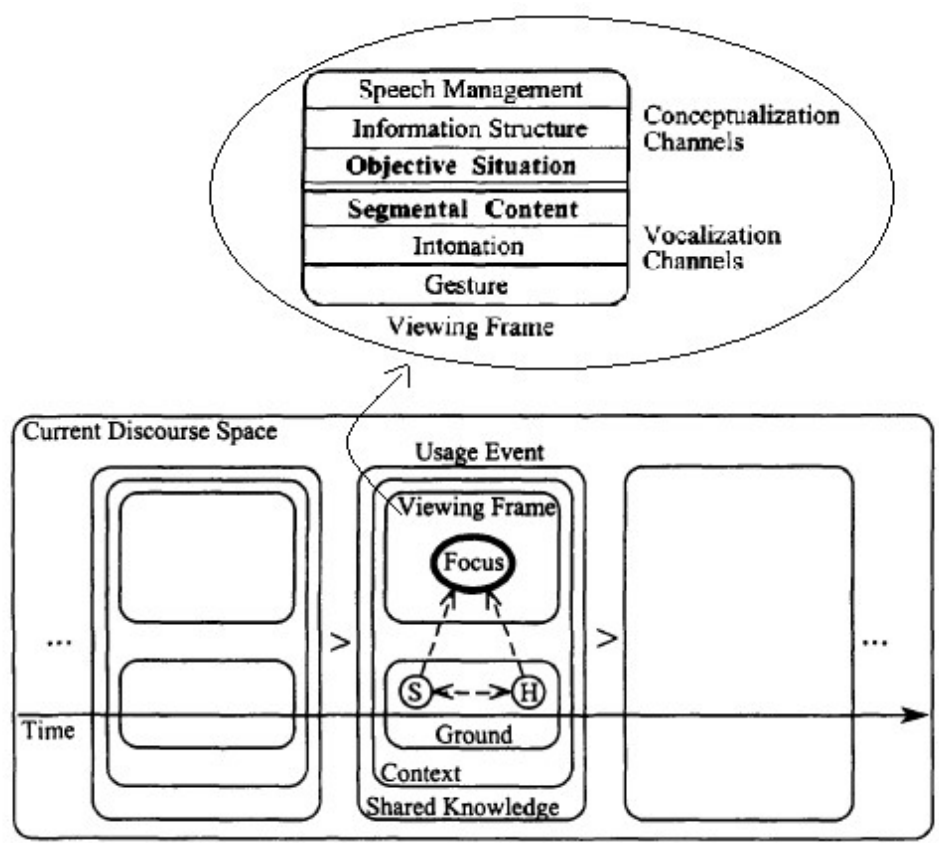

Figure 1 - Current Discourse Space Source: adapted from Langacker (2001, p. 145-146)

This Current Discourse Space includes a body of accessible or shared knowledge by the participants; the Context of Speech includes broadly, the physical, mental, social and cultural background. The Ground at the center of the Context of Speech comprises the particular facet of the world that the participants are engaged with. The speaker has an initiative role and the hearer a responsive one, but neither role is active or reactive, since both actively deal with conceptualization and vocalization. Their action directs the focusing of attention to the same conceived entity at a given instant, that is, they both are "looking at" the viewing frame. The viewing frame is composed by independent but coordinated multiple 


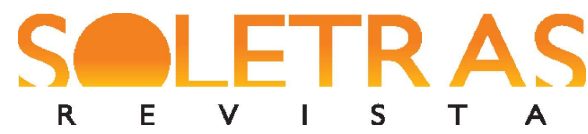

N. 41 - 2021.1 - LUIS FILIPE LIMA E SILVA

RONALDO RODRIGUES DE PAULA

channels that deal with both conceptualization and vocalization. Some element in the immediate scope of their momentary viewing frame is their focus of attention. In regard to the flow of attention management in the flow of discourse, the attention windows, they are marked by intonation units such as pauses, breaks in timing, acceleration and deceleration, changes in pitch, etc. The linguistic structures of a given language are instructions to modify or adapt the Current Discourse Space to a specific desired form. The whole discourse event is a series of frames depicted in figure 1, viewed and acted upon by the discourse participants.

Returning to the notions of Topic and subject, their relationship has been noticed in linguistic studies for a long time. A Topic establishes a link between an entity, or an abstraction, or a thing, etc. and a proposition, whereas the subject is a point of reference established by a verb in a clause. Li \& Thompson (1976, p. 484 apud Langacker, 2001) claim that subjects are essentially grammaticalized Topics.

Langacker (2001) argued that Lexical and Grammatical elements display particular ways of construct their conceptual content, their conventional meaning so to speak. The more schematic or less fine grained specific a linguistic expression is semantically, more it tends to be considered "grammatical" rather than "lexical". For our purpose in this paper, we will focus on the notion of Prominence regarding the construal nature of meaning. As proposed by the author, in relation to Grammar, there are two kinds of Prominence which are particularly relevant: Profiling and Degree of Salience.

Profile is the relation, or the substructure that an expression draws attention to from its conceptual base. Consider, for example, the figure 2 below.

(a)

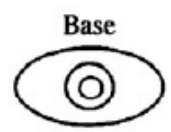

(b)

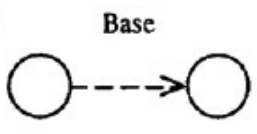

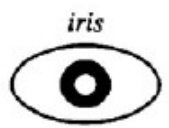

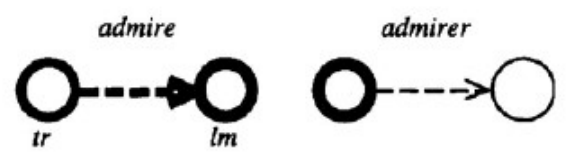

Figure 2 - Base and Profile

Source: adapted from Langacker (2001, p. 18)

Notice that in Figure 2(a), the human eye is the conceptual base for iris and pupil. They differ semantically by being different profiles of the conceptual base. In 2 (b), we see a 


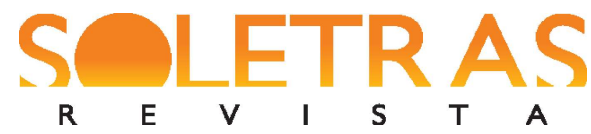

N. 41 - 2021.1 - LUIS FILIPE LIMA E SILVA

RONALDO RODRIGUES DE PAULA

profile expressing not a thing, but a relationship. The profile is indicated by heavy lines. The author argues that an expression's grammatical class is determined by its profile. For example, a noun profiles a thing, a verb profiles a process, understood as a relationship that endures through a determined time, and other classes represent non-processual relations such as adjectives and prepositions.

The Degree of Salience represents the focal prominence related to one or more participants. According to Langacker (2001, p. 19-20) words:

(...) It is usual for one participant - termed the trajector (tr) - to stand out as the primary focal participant in the sense of being the one the expression is concerned with locating, characterizing, or assessing in relation to others. A secondary focal participant, with respect to which the trajector is located or evaluated, is called a landmark $(\mathrm{lm})$. (LANGACKER, 2001, p. 19-20)

It is important to mention that, in a profiling relationship, the subject is the trajector and the object the landmark. The same configuration is assumed for Topic and Comment, the former is a trajector and the latter is a landmark.

\section{How Subject and Anacoluthon NPs in Topic are manifested cognitively}

Langacker (2001) claims that the subject is the nominal that act as a trajector in the sentential level. Notwithstanding, the Topic is always extrinsic to that level, even though it is also a trajector. Upon that assumption, two distinct levels can be identified; the sentential level, where the grammatical computations take place in the lexicon, and the discourse level, a level which includes a large array of linguistic phenomena such as the informational structure, the temporal and processing chain, the windows of attention, etc. What the data shows us is that the sentential trajector can co-occur with a discursive trajector, as in the examples 2 and 3. That is, the NPs el chalecito 'the little vest' and la tía Mari 'aunt Mary' are the subjects of their respective sentences, thus they are trajectors at the sentential level. Observe that they figure in the Topic information unit, which is a trajector in the discursive level. Therefore, it is possible to argue that there is congruence between the trajectors in those two levels of 


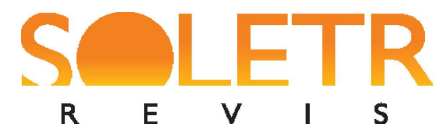

linguistic structure, which means that two primary focuses would be aligned at the same direction on the temporal chain ${ }^{5}$.

(2) *CAR: el chalecito / TOP tenía muchísimo encanto //COM

'The little vest / had a lot of charm'

(3) *PIU: la tía Mari / ${ }^{\mathrm{TOP}}$ no soltaba el pitillo //COM

'Aunt Mary / did not let go her cigarette'

The sentential level is related to computations applied to the lexical items. Nonetheless, Topic belongs to the discursive level and function on the interface between the prosodic and pragmatic domains. Thereupon, it is not straightforwardly related to the lexicon computations, given its sentential extrinsic nature. In this sense, in contraposition to examples 2 and 3, there are many instances that the utterances' information structure does not yield canonical sentences, as in the examples 4 and 5 .

(4) *PIU: también Ana /TOP están todos los nietos de < todos $>/ /$ COM

'Including Ana / all the grandchildren of everybody are here'

(5) *CHU: <la boquilla dorada> /TOP eso era lo más //COM

'The golden mouthpiece / that was the most'

In these instances, the sentential trajector is absent so that only the discursive trajector is realized in the utterance. Any NP in Topic which does not hold any syntactic relation with the following content cannot act as a trajector in the sentential level given that there is no trajector without a landmark or Figure without Ground.

In regard to this proposal, the following figures 3 and 4 illustrate the examples 6 and 7 , respectively:

(6) *PIU: <la tía Elvira /TOP fumó de soltera $>/ /^{\mathrm{COM}}$

\footnotetext{
5 The Spanish examples presented in this paper were collected from IPIC corpus (NICOLÁS MARTÍNEZ; LOMBÁN SOMACARRERA, 2018). 


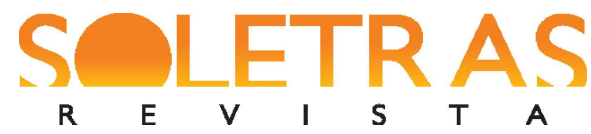

N. $41-2021.1$ - LUIS FILIPE LIMA E SILVA

RONALDO RODRIGUES DE PAULA

'Aunt Elvira / smoked as a bachelorette'

(7) *COC: número /TOP yo les doy ahora / ${ }^{\mathrm{COM}}$ corazón //ALL

'Number / I give it to you now / sweetheart'

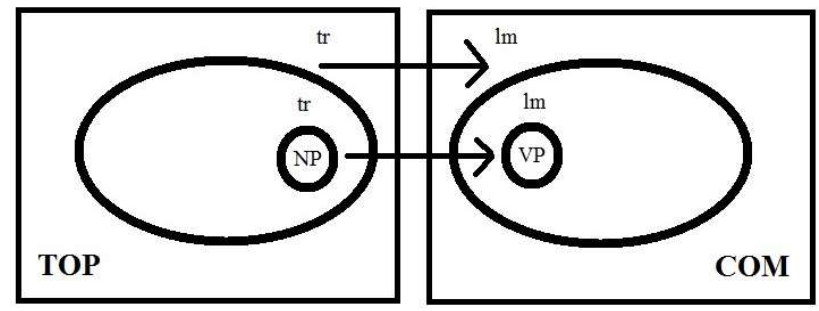

Figure 3 - Alignment trajector and landmark at the discursive and sentential levels Source: Elaborated by the authors.

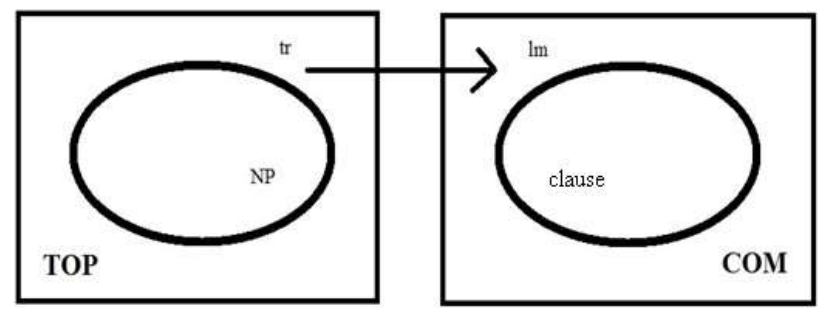

Figure 4 - Alignment trajector and Landmark at discursive level Source: Elaborated by the authors.

Notice that, in figure 4 , there is a possibility that the subject NP in TOP can also be comprised in one single COM unit. However, the distinction to draw in relation to figure 3 is that the trajector at the discursive level highlights the subject NP in the prosodic domain.

In a broad view this phenomenon can be described as an asymmetric organization of baseline (B) and elaboration (E), in which $\mathrm{B}$ is an established object and $\mathrm{E}$ is a mapping function that yields a structure of superior level BE, as conceptualized by Langacker (2016). $\mathrm{B}$, therefore, offers the scope to a computation in which $\mathrm{E}$ can perform. This kind of computation is successively subdivided in strata, so that each substratum constitutes a B for the next one. Such arrangement creates more and more complex structures. In conceptual terms, that would enable a chain of serial access, in which every element is accessed individually but not in isolation. As the sequence is not accidental, that is, it constitutes a 

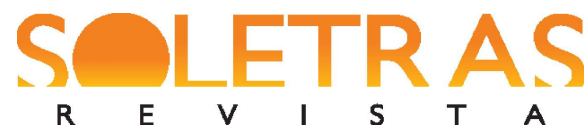

N. 41 - 2021.1 - LUIS FILIPE LIMA E SILVA

RONALDO RODRIGUES DE PAULA

base; the activation of an element facilitates the activation of the next. Langacker (2016) illustrates this serial access with the recitation of the alphabet, which comprises comparable elements arranged in a certain spaced sequence: $\mathrm{A}>\mathrm{B}>\mathrm{C}>\mathrm{D}$... At the moment of recitation, each letter is momentarily focused on its own window of attention $(A)>(B)>(C)>(D) \ldots$ Each subsequent letter is seized in relation to the previous one in a serial process. In regard to this issue, the author assumes that:

Successive elements must therefore be connected via relationships manifested in larger processing windows. I assume that processing runs concurrently on different time scales, in windows of different duration, each a scope of awareness allowing co-occurring elements to form relationships (LANGACKER, 2016, p. 408).

In serial access, each window of attention is activated by prosodic windows consecutively presented. In structural terms, this conception is translated in autonomous structures (A) and dependent ones (D). A dependent structure needs a support of an autonomous structure for its full manifestation. In this matter, D elaborates A in order to form a superior level $A D$ structure, resulting in the building of layering: ((( (A) $\left.\left.\left.D_{A}\right) D_{A}\right) D_{A}\right)$. Such structural layering is believed to happen in TOP-COM articulation, since TOP is a unit which depends on COM in prosodic-informational terms. In the syntactic viewpoint, dependent element structures such as 6 and 7 can be thought in layering representation. In the conceptual viewpoint their access would be built by serial activation, as in figure 5 .

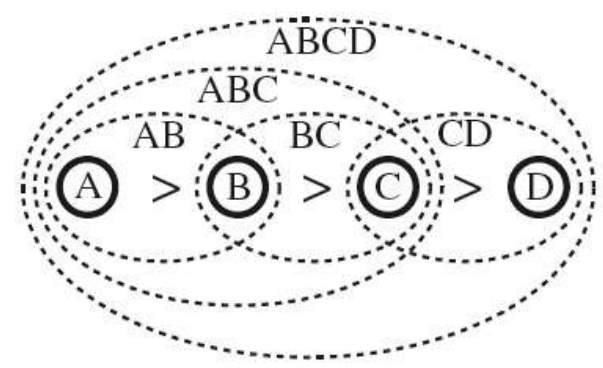

Figure 5 - Serial access in distinct windows of attention

Source: Langacker (2016) 
Conceptually, the access can also be granted by global awareness of all the activated elements so far, comprising a series of larger groups acting in windows of a longer duration. This kind of access, which is termed cumulative, represents consecutively paired structures: $(\mathrm{A})>((\mathrm{A}) \mathrm{B})>(((\mathrm{A}) \mathrm{B}) \mathrm{C})>((((\mathrm{A}) \mathrm{B}) \mathrm{C}) \mathrm{D})$. Cases that these structures predominantly occur are called summation. Langacker (2016) claims that there is a cumulative aspect in the discourse. On his words: "The summation of conceptual content results in a more and more elaborated apprehension of the situation under discussion" (LANGACKER, 2016, p. 410). It is important to mention that the serial access can result in incremental increase by summation; therefore there is not only gradation, but also an access conceptual continuum. The author instantiate this with possessive structures which are cumulatively apprehended by serial presenting: Joe > Joe's wife > Joe's wife's mother > Joe's wife's mother's estate.

In this sense, TOP-COM articulation activates its serial access at the discursive level. In this perspective, the process can result in a layering structure, as well as serial access via summation. We can argue that the summation would be the kind of structural computation occurring in those cases in which there is not a syntactic relation between the elements in a given information structure as in the examples 5 and 7. In these cases, there is not any lexical dependency, that is, the elements in TOP and in COM are autonomous in the syntactic domain, so they are apprehended from cumulative access, via summation of the activated elements from the beginning of the utterance. Otherwise, the layering computation could be incompatible in this situation, since this approach is based in dependency relations.

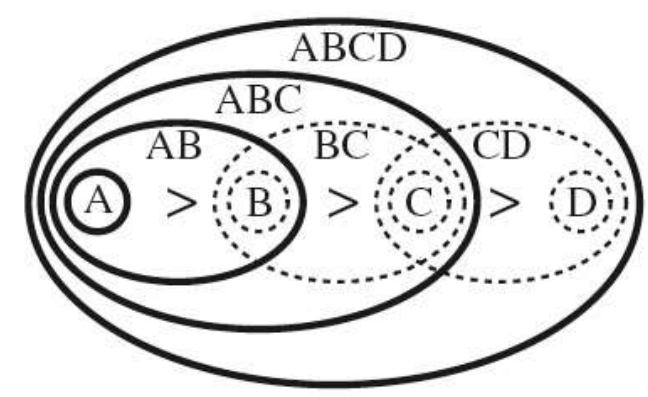

Figure 6 - Cumulative access in distinct windows of attention Source: Langacker (2016)

In the next section, we explore anacoluthon NPs as Topics from Gestalt psychology's approach. 


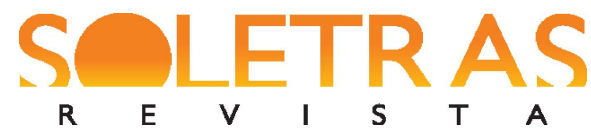

N. 41 - 2021.1 - LUIS FILIPE LIMA E SILVA

RONALDO RODRIGUES DE PAULA

\section{Anacoluthon NPs according to Gestalt psychology's approach}

Check out the following speech example in $(8)^{6}$. The context is about an accusation of the former Brazil's presidency candidate, Corporal Daciolo, in 2018 regarding a supposed involvement of the pastors Silas Malafaia and Marco Feliciano with the freemasonry. Corporal Daciolo prays asking that the aforementioned pastors could break ties with the freemasonry. Note that in the utterances 5 and 8 , the speaker uses glossolalia, that is, a language unknown by the speaker, in this context supposedly attributed to a divine intervention, commonly known as the angel's language (cf. SAMARIN, 1972).

(8) *DAC: [1] Senhor / coloco o Silas Malafaia / e o Marco Feliciano em tuas mãos / Pai // [2] olha eles aí / Senhor // [3] que o Senhor possa tocar no coração deles e que possa pelo arrependimento / Pai // [4] que eles possam te servir / Senhor // [5] hamanarashanarai // [6] que eles venham largar essa maçonaria / Pai // [7] que eles venham sair / Senhor // [8] hamanarashanarai // [9] em nome do Senhor Jesus Cristo // [10] em nome do / Senhor / Jesus Cristo // [11] agora eu quero falar algo mais importante ainda // [12] eles /TOP Deus tá vendo tudo //COM [13] Deus vai revelar // [14] eu não tô aqui / varão + [15] se eu quisesse voto / se eu tivesse atrás de voto / eu não taria falando isso //

*DAC: [1] Lord / I put Silas Malafaia / and Marco Feliciano in your hands / Father // [2] look at them over there / Lord // [3] may the Lord touch their hearts and may they repent / Father // [4] may they can serve you / Lord // [5] hamanarashanarai // [6] may they will drop this freemasonry / Father // [7] may they come out / Lord // [8] hamanarashanarai // [9] in the name of Our Lord Jesus Christ // [10] in the name of / Our Lord / Jesus Christ // [11] now I want to talk about something even more important // [12] they / ${ }^{\text {TOP }}$ God is seeing everything //COM [13] God will reveal // [14] I'm not here / man + [15] if I wanted votes / if I was seeking votes / I wouldn't be saying that //

The utterance 12, performed after the prayer, is an instance of the informational articulation of the type TOP-COM: "eles / ${ }^{\mathrm{TOP}}$ Deus tá vendo tudo //COM" (they / ${ }^{\mathrm{TOP}}$ God is seeing everything $\left./ /^{\mathrm{COM}}\right)$. The third person plural pronoun is an anacoluthon. This utterance could be paraphrased as follows "In regard to them, God is seeing everything". The usage of the prosodic break and the melodic pattern of TOP are for the purpose of isolating the syntactic unattached NP from the following content of the utterance which, in this case, is a

6 Available at: <https://www.youtube.com/watch?v=xoqrQIO_EdU>. This stretch was transcribed and segmented by us. 


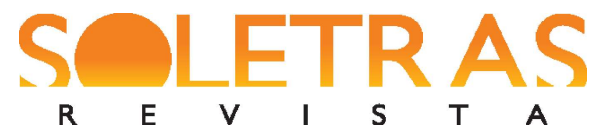

N. $41-2021.1$ - LUIS FILIPE LIMA E SILVA

RONALDO RODRIGUES DE PAULA

complete syntactic structure. That is a resort that helps the processing of this kind of structure, since the speaker do not need to reanalyze the NPs that do not bear a syntactic relation with the others realized in one single tonal unit. The prosodic-information break between elements that do not bear any syntactic relation is a common strategy at the language's disposal for the isolation of the anacoluthon. Silva (2020a, 2020b) claims that the major tendency of the anacolutha being divided prosodically and informationally is one of the principles of the speech's syntax computation in utterance's realization. In a higher rate of speech, there is a possibility that the anacoluthon be uttered on the same informational unit of the following content. However, that potentially could affect the interpretation of the utterance's elements. A hypothesis to be explored in this matter is related to a possible perception of a prosodic break that could safeguard the aforementioned principle of the separation of the anacolutha through prosody and information structure in such cases. Or in other words, speakers would perceive the prosodic break even in its absence. That would explain those cases where there are "mistakes" in information labeling, where the labellers indicate that there is just one informational unit, commonly TOP, in contexts where the anacolutha are perceived within the same tonal unit. Thus, at the perception viewpoint, the subjects tend to individualize a break so that the utterance could be successfully interpreted. In that regard, in the means of better testing this hypothesis, a psycholinguist experiment would be in order. In the next section let us turn to the Gestalt psychology's theoretical approach.

\section{Gestalt psychology}

Gestalt psychology (cf. KOFFKA, 1936[1935]; KÖHLER, 1992[1947]) is a theoretical approach which provides a solid base for data analysis such as the utterance 12 of the example 8. The perception has an important role in this framework. To scholars of the Gestalt psychology the process of perception lies between stimulus and response. Therefore, the behavior should be studied taking into account the possible conditions that can affect the perception of the stimulus. Moreover, the perception would require not just the display of the sensorial elements allocated in their physical bases. The scholars of this framework notice that some phenomena leads to a characterization of a perceptual constancy, that is, "[a] quality of 


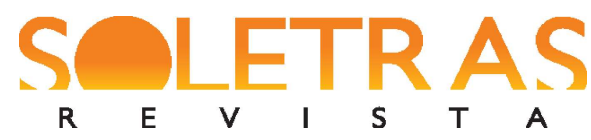

N. 41 - 2021.1 - LUIS FILIPE LIMA E SILVA

RONALDO RODRIGUES DE PAULA

wholeness or completeness in perceptual experience that does not vary even when the sensory elements change" (SCHULTZ; SCHULTZ, 2011, p. 271). That happens, for instance, when the brightness or the size of the sensorial elements change but the perception remains constant. There is a tendency that the objects be perceived with stable features in space, such as shape, size, brightness, location and color.

Consequently, there is a difference between the sensorial stimulus and the resulting perception. In that regard, the wholeness or completeness quality cannot be found in any component part of the elements. Thus, the perception cannot be explained by the addition of the elements' parts. It is a whole, that is, a Gestalt. Our perception of the objects is a unified whole, not the addition of individual sensations. At this point, it is important to draw the difference between sensation and perception. The sensation is the "(...) stimulation of sense organs"; whereas the perception is "(...) the selection organization, and interpretation of sensory input" (WEITEN, 2017, p. 107). The sensory organs absorb energy such as the light, the sound waves and then send information to the brain in order to do the processing and interpretation ${ }^{7}$. That becomes clear when we come to know what is called agnosia, that is, the inability of processing sensory information. In visual agnosia cases, for instance, the individual normally sees, but (s)he is unable to recognize what (s)he is seeing. That is, the individual's visual system is intact allowing this particular individual to absorb all the sensorial stimuli through the visual organ, making it possible to see the objects. Nonetheless, (s)he is incapable of interpreting those stimuli transmitted to the brain. For that reason, the identification and recognition of objects become impossible. According to Farah (2004): "In striking contrast to their roughly intact visual sensory functions, visual form agnosics are severely impaired at recognizing, matching, copying, or discriminating simple visual stimuli" (FARAH, 2004, p. 13). This condition is a result of posterior inferior visual association cortex injuries (cf. DEVINSKY; D’ESPOSITO, 2004).

The perception of an object is guided by a tendency to shape balance maintenance, which is regulated by a law. The law of pregnancy (Prägnanz $)^{8}$, or law of good shape, states that the physical systems are always comprised of total forces' interaction. Such forces are always organized seeking the simplest and symmetrical shape possible. As Gestalt scholars

\footnotetext{
${ }^{7}$ In addition to sight and hearing, other senses should also be considered such as touch, smell and taste.

${ }^{8}$ We opted to adopt here the same terms crafted in the seminal works of Gestalt Psychology, namely Koffka (1935) and Köhler (1947).
} 


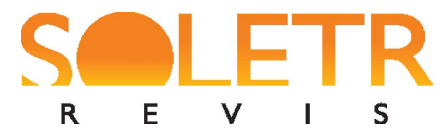

claim that there is an isomorphism between the brain's activities patterns and the conscious experience or, in other words, the perceptual fields are reflexes of the brains' activities patterns, then the perception must obey the brain's force fields distribution, which tends to be simple and symmetric. Therefore, even if the sensorial information is fragmented and incomplete, the cognitive experience would be complete and neat, since the sensorial information interacts with the brain's force fields. The law of pregnancy claims that

(...) psychological organization will always be as good as conditions allow because fields of brain activity will always distribute themselves in the simplest way possible under the prevailing conditions, just as other physical force fields do. The law of Prägnanz asserts that all cognitive experiences will tend to be as organized, symmetrical simple, and regular as they can be, given the pattern of brain activity at any given moment. (HERGENHAHN, 2009, p. 466)

Notwithstanding, the elements are not always perceived as balanced, symmetric, stable and simple. When they are not, the law of pregnancy will not act in an effective way. For instance, the figure that follows does not show the aforementioned basic aspects, for that matter it is an optical illusion that the perception cannot surpass.

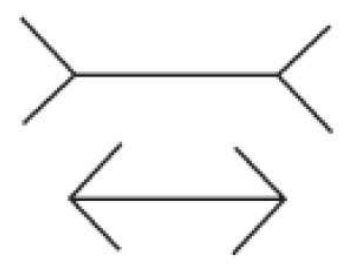

Figure 7 - Müller-Lyer Illusion

Source: Deroy (2015)

This illusion is about the size of the straight lines. The first one is perceived as larger than the second, although both have the same size. That can be verified in the adaptation of the same figure below. The parallel vertical red lines show that the both horizontal straight lines have the exact same size. 


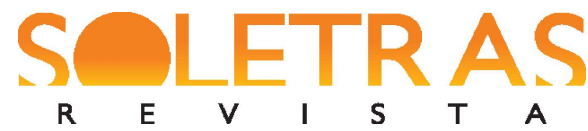

N. 41 - 2021.1 - LUIS FILIPE LIMA E SILVA

RONALDO RODRIGUES DE PAULA

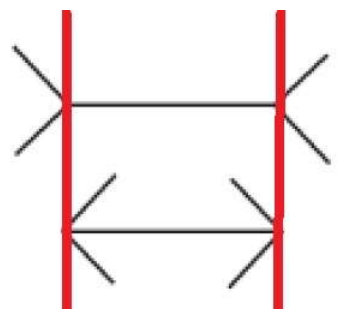

Figure 8 - Müller-Lyer illusion revealed

Source: Deroy (2015), adapted

Gestalt scholars believe that the stimuli perception determine behavior. Therefore, it is subject to law of pregnancy. They termed environment the stimuli set that determines behavior. Yet, there are two environments: the geographic and the behavioral one. The geographic environment matches to the physical environment. On the other hand, the behavioral environment corresponds to the result of the individual's interaction with the geographic environment, which leads it to the interpretation of this environment through the forces that rule perception such as simplicity, stability, balance and symmetry. To make clear the difference between these two environments, imagine a common situation, akin to have happened to the reader, in which one waves at a unknown person in the distance believing that it is someone (s)he knows, but as the person gets closer, (s)he realizes that it is not the person (s)he thought to be. As waving at the unknown person, (s)he believes that it is someone (s)he knows. Such confusion shows that stimuli perception in the environment conditions in which one finds them are intermediated by the way one interprets the stimuli. The behavioral environment corresponds to one's subjective interpretation triggered through one's interaction with the geographic environment. Behavior, thus, is determined by the perception of the behavioral environment. The resemblance of the two people in aforementioned situation is the cause of the mistake. Consequently, there was a tendency to establish the similarities between those people instead of their differences. The tendency to connect the elements is termed psychological force field. The psychological field, in its turn, is correspondent to a force field that seeks the good shape or the pregnancy. Bock et al. (2001) claims that such psychological force field "has a tendency that guarantees the search for the best possible shape in situations 


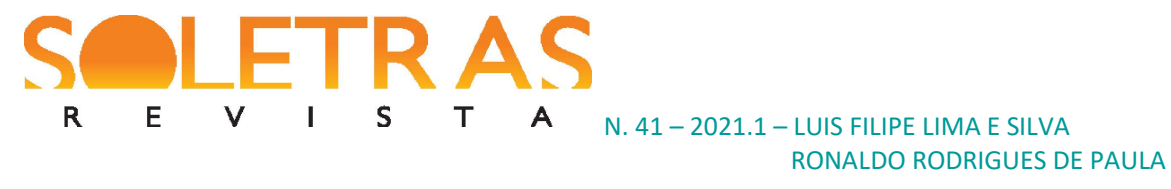

that are not very well structured" (BOCK et al. 2001, p. 63) ${ }^{9}$. This process unfolds according certain laws or principles listed below ${ }^{10}$.

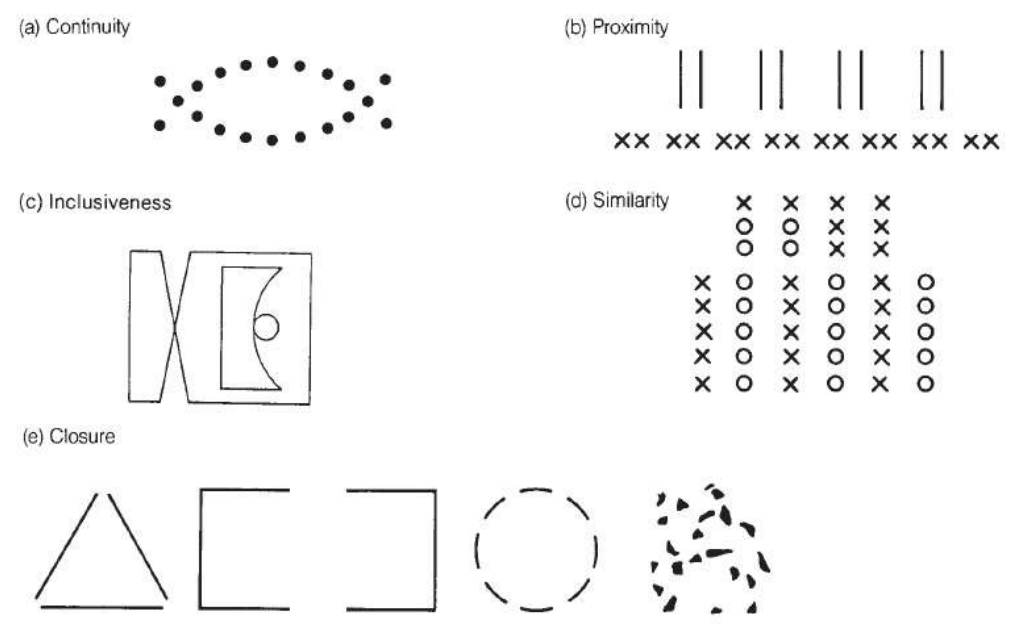

Figure 9 - Gestalt principles

Source: Sartain et al. (1973) apud Hergenhahn (2009)

The continuity principle states that the stimuli that we distribute in a continuous way will be viewed as a unit in perception. The figure (9a) illustrates dots arranged one after the other, which creates a perception of a continuous unit. The pattern of continuity that this figure evokes cannot be found in any of the individual dots in isolation. As these dots are arranged in the same direction, they constitute a pattern or configuration. The proximity principle states that when the stimuli are close to one another, they tend to be grouped or perceived as a unit. The figure (9b) illustrates this, in such a way that the lines and the Xs are seeing as a group of pairs instead of individual lines and Xs. The inclusivity principle claims that when there is more than one figure in the stimuli, there is a tendency that the figure which contains the large number of stimuli has priority in perception. In figure (9c), it is difficult to perceive the symbol $\sqrt{ } 16$ because the parts that integrate it are arranged in a larger figure. The camouflage follows this principle, insofar as the camouflaged object in the color of the physical environment where the object is ends up blending in and the detection becomes more difficult. The similarity principle states that the similar objects tend to form perception units.

\footnotetext{
${ }^{9}$ Our translation for: "tem uma tendência que garante a busca da melhor forma possível em situações que não estão muito estruturadas".

${ }^{10}$ Such principles vary in number in the literature. In this paper we consider Sartain et al. (1973)'s list.
} 


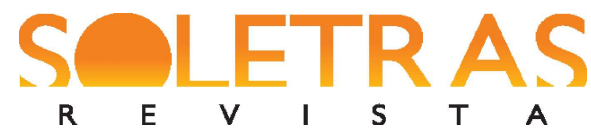

N. 41 - 2021.1 - LUIS FILIPE LIMA E SILVA

RONALDO RODRIGUES DE PAULA

In figure (9d), the circles and the Xs form each other a perception unit because they are similar. The same happens, for instance, in a soccer match where the players of their respective teams use uniforms, and thus, we group them according to the similarity principle. The closure principle consists in incomplete figures that are understood as complete units. The figure (9e) shows that even with gaps we can notice the shapes in question as real geometric forms, such as the triangle, rectangle and circle. The transformation of the stimulus performed by the brain rearranges these figures in such configurations that we can experience them cognitively. That makes possible for us perceive the last stimulus of figure (9e) as a person riding a horse.

A very important additional principle for the forthcoming analysis is the configuration figure-ground. This principle consists in the division of the perceptive field in two parts: "the figure, which is clear and unified and is the object of attention, and the ground, which is diffuse and consists on everything that is not being attended to" (HERGENHAHN, 2009, p. 468 , italics by the author). The change of attention is capable of altering what is figure and what is ground.

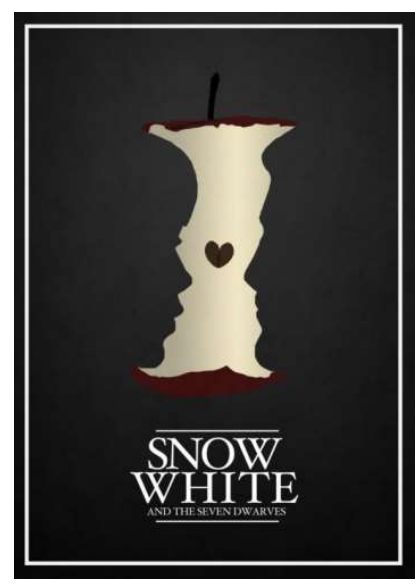

Figure 10 - Poster of Snow White history

Source: $<$ https://www.elo7.com.br/poster-a4-snow-white/dp/C90E1A>

In figure (10), we can notice that, depending on where we focus our attention, we see an apple with its core or the profile of Snow White and the Prince separated by a heart. It is interesting to realize that the brain cannot process both shapes at the same time. Therefore, if the attention is on the apple, it will be the figure and the profiles will be the ground, on the other hand, if the attention is on the profiles, they will be the figure and the apple will be the ground. We focus our attention in only one shape per time. This principle was established by 
the Danish psychologist Edgar Rubin (1886-1951). The famous image that was used in his work became known as "The Rubin's vase" is depicted bellow.

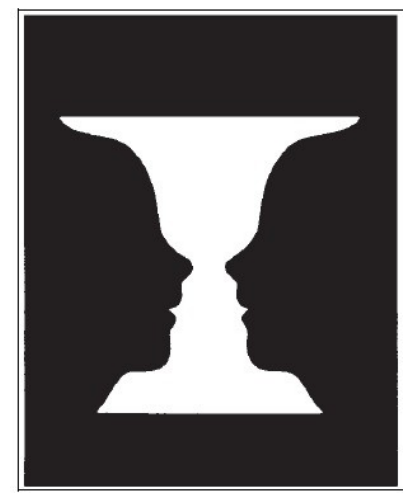

Figure 11 - Rubin's vase

Source: Rubin (1921/1915) apud Hergenhahn (2009)

Depending on where we focus our attention, we notice a white vase or the profile of two people facing each other. When we focus our attention on the vase, it becomes the figure and the profiles become the ground, and vice-versa. Once again, that shows that the brain cannot process the vase and the profiles at the same time. It's important to highlight that the Gestalt's principles are not only applicable to visual field. They have been applied, for instance, in education (HARTMANN, 1966), in music (TENNEY; POLANSKY, 1980), in physics (LEZAMA et al. 2014), in neuroscience (HASSON et al. 2001), in psychological therapy practice (WOLDT; TOMAN, 2005), as well as in linguistics (TALMY, 1975; 2000; FUKUI, 2014).

In the next section, we turn to anacolutha.

\section{How the anacolutha are organized in spontaneous speech}

Let us return to the example quoted in the beginning of this section used to illustrate how the anacolutha are set in spontaneous speech in general:

(9) *DAC: [12] eles / ${ }^{\mathrm{TOP}}$ Deus tá vendo tudo //COM

'They / God is seeing everything' 
In order to analyze the spontaneous speech data as in (9) using some Gestalt's principle, it is necessary to realize that the analysis should be based on stimulus' features. As the stimulus is the speech in this case, its peculiar features must be consider in the analysis, taking into the account the fact that they are different from the stimulus of visual field features. The speech is a dynamical event which unfolds through time. It comprises lexical items hierarchically distributed according to the syntactic computations of the language. In this regard, aspects as the bright, color and luminosity do not take place in speech phenomenon. The main difference between visual field stimulus and speech field stimulus is that the first unfolds through space and the latter unfolds through time, as aforementioned. The comprehension that the transcription of the speech event does not replace the speech phenomenon itself is also a factor that should be considered. Consequently, analyzing a speech utterance based on its transcription would be deceiving. The transcription is a resource to register an event, but it does not constitute and neither replaces the inherent features of the speech, as the sound waves which are transmitted through the air and unfold along the time axis.

Taking the many Gestalt's principles into account and adapting them to the speech event, the one that would best describe anacolutha would be the figure-ground configuration. An important step to understand that comes from the observation of the argument structure of the verb and the distribution of the lexical heads. The verb ver 'to see' is a verb which comprises two heads, an internal and an external head. Therefore, both the insertion of a third head or the removal of one, either in subject or object positions, would make the sentence ungrammatical, as displayed bellow:
a. O João viu a Maria. 'John saw Mary'
b. *O João o Carlos viu a Maria. 'John Charles saw Mary'
c. *O João viu a Maria o carro. 'John saw Mary the car'
d. *O João viu. 'John saw'
e. *Viu Maria. 'Saw Mary' 


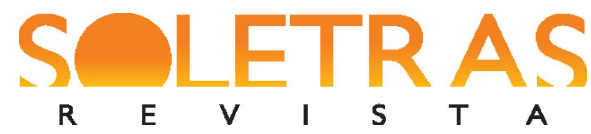

N. $41-2021.1$ - LUIS FILIPE LIMA E SILVA

RONALDO RODRIGUES DE PAULA

The sentences (10b) and (10c) become grammatical if the NPs are coordinated, but that requires the realization of a conjunction between the nouns. In the example (9), the heads of the verb ver are fulfilled by the noun Deus and by the pronoun tudo. Thus, there is no place for the pronoun eles, and that is exactly what makes it an anacoluthon, that is, an element that does not have any syntactic relation with the following sentence. Note that there is the possibility that the third person plural pronoun could be the internal head of the verb; nonetheless, the interpretation of the utterance is different so that the original sense of the utterance is altered:

a. eles / Deus tá vendo tudo $\rightarrow$ "regarding them / God is seeing everything [what they are doing]"

b. Deus tá vendo eles tudo $\rightarrow$ "God sees them all"

In visual field, the brain cannot process two shapes at the same time. In speech, we propose that neither can the brain process the third person plural as a head of the verb ver, that is, or 'Eles tá vendo tudo' or 'Deus tá vendo tudo'. The processing of the structure 'Eles Deus tá vendo tudo' is not possible, thus this utterance is ungrammatical. As a result, the third person plural pronoun is the figure and the following sentence is the ground. What determines the pronoun as figure is its realization as the information unit of TOP, realized with a prosodic prominence that highlights it. Other studies have already placed the Topic as the figure or the trajector at discursive level (cf. LANGACKER, 2001; SILVA, 2020a). As the speech unfolds temporally, the perception of the anacoluthon in TOP as the figure and the sentence in COM as the ground is irreversible. That means that the possibility of figure-ground symmetry, in such a way that the sentence in COM could be perceived sometimes as figure, sometimes as ground is out of question. What turns possible that the processing of the utterance could be performed is the fact that the anacoluthon is apart from the sentence to which is related by a prosodic break with informational value that even has the function of being the application field of the illocutionary force in COM (cf. CAVALCANTE, 2020). That is the reason why in the situations when the speaker increases its speech rate, possibly making imperceptible the prosodic break that highlights the anacoluthon in TOP, the interlocutors would perceive the 


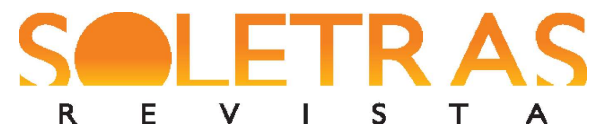

N. $41-2021.1$ - LUIS FILIPE LIMA E SILVA

RONALDO RODRIGUES DE PAULA

realization of the break even so. Otherwise the full interpretation of the utterance would be compromised, that is, the utterance would be perceived as ungrammatical. So, a syntactic structure would lead to the perception of a corresponding prosodic unit. That would not be a new phenomenon, since there are illusions in the auditory level as there are optical illusions (cf. DEUSTCH, 2019). These illusions are related to the speech level as much as the musical level. As an example, we can quote the case of the missing fundamental, which consists in the audition of a fundamental frequency that is absent in the harmonic series, but it is inferred from the higher frequencies of the series. Regarding this matter, according to Loy (2006)

Suppose the partials of the complex tone are 300, 400, and $500 \mathrm{~Hz}$. You will most likely distinctly hear a "fundamental" at $100 \mathrm{~Hz}$, the greatest common factor of the overtones. You will not hear an inharmonic tone with fundamental at $300 \mathrm{~Hz}$. So convinced are our ears of the ubiquitous phenomenon of a fundamental with harmonics at integer multiples that even if there is no fundamental, our hearing is hardwired to invent one. (LOY, 2006, p. 157)

Koffka (1936[1935]) mentions that there is a double representation in certain figureground configuration cases. More specifically, in the cases which a minor figure is included in a larger one. The smaller figure is represented twice, once as the minor figure and twice as a part of the larger one. Turning to the anacolutha, the same phenomenon seems to apply. The TOP which includes the anacoluthon is part of the utterance, dividing it in two parts, one contains the TOP itself and the other relates it to COM. The difference is that the TOP, contrary to the minor figure, cannot be realized without the realization of COM. As aforementioned, TOP is always related to COM, providing the environment where the illocutionary force is applied. Therefore, the anacoluthon in TOP is conditioned to the application of the illocution in COM. That straightly corresponds to the functional dependency principle established between figure and ground. Koffka (1936[1935]) explains this principle arguing that “(...) the figure depends for its characteristics upon the ground on which it appears. The ground serves as a framework in which the figure is suspended and thereby determines the figure" (KOFFKA, 1936[1935], p. 184). As the anacoluthon in TOP is the figure, it depends on the illocution in COM, which is the reason for what it is performed in 


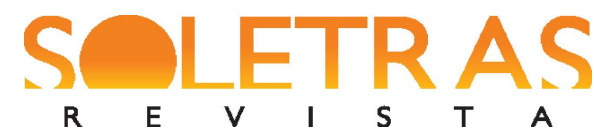

N. 41 - 2021.1 - LUIS FILIPE LIMA E SILVA

RONALDO RODRIGUES DE PAULA

the utterance. Thus, the ground, or the illocution in COM, determines the realization of the anacoluthon in TOP, since without illocution there would be no TOP and without a complete syntactic structure in COM there would be no anacoluthon in TOP. For instance, if the argument structure is not completely fulfilled in COM, the element in TOP would not be an anacoluthon, but the subject, as the following utterances show:

a. O João / ${ }^{\mathrm{TOP}}$ a esposa dele saiu às compras hoje //COM

'In regards to John / his wife went shopping today //

b. O João / ${ }^{\mathrm{TOP}}$ saiu às compras hoje //COM

'John / went shopping today //

In (12a), the argument structure of the verb sair is fulfilled by the subject NP a esposa dele. Then the NP O João can only be an anacoluthon. In (12b) the argument structure of the verb sair is not fulfilled by any subject NP in COM, so the subject can only be the NP O João in TOP which fulfill the argument structure of the verb sair in COM. Koffka (1936[1935]) affirms that "the contours which shape the figure do not shape its ground; if the later has a shape, it owes this to other forces than those which produce the figure upon it." (KOFFKA, 1936[1935], p. 184). In our case, we can extrapolate that the prosodic contour which shapes the anacoluthon in TOP is not the same that shapes COM, which is the ground. The contour that shapes the COM is from a different nature, representing an illocution. The illocution prosodic contours never match to the prosodic contour of TOP. The TOP has specific prosodic patterns that allows us characterize it as distinct information unit from the COM as well as other information units (cf. HEDBERG; SOSA, 2008), whereas each illocution has its own prosodic pattern (MORAES; RILLIARD, 2018). It is interesting to notice that Koffka (1936[1935]) had already come up with the possibility that the figure-ground configuration could be present in all of our senses. According to the author, “(...) the distinction holds for all the senses. For audition, it is clear; we can hear speech on the background of the patter of the rain, or the roaring of a mountain stream" (KOFFKA, 1936[1935], p. 200). That means that the application of the concept figure-ground to the structure of the speech is pertinent whereas it is transmitted by sound waves which are spread through the air captured by the sense of 


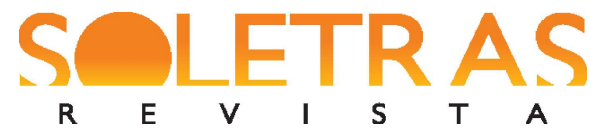

N. $41-2021.1$ - LUIS FILIPE LIMA E SILVA

RONALDO RODRIGUES DE PAULA

hearing. Although the assumptions made in this section lack an experimental approach in order to validate them, we believe that they provide a theoretical base to the application in the experimental scope.

\section{Final Remarks}

In this paper we analyzed the closed relationship of subjects and anacolutha NPs in Topic, both from the perspective of Cognitive Grammar and from the perspective of the field of Psychology which it was derived, that is, the Gestalt approach. While an anacoluthon is a trajector only in discursive level, a NP subject in Topic functions as a trajector concomitantly in both discursive and sentential level. Regarding the Gestalt approach, we can refer to anacoluthon as a figure in which the illocutionary force in Comment is the ground, the only difference regarding to visual elements is that as the latter is comprised only by space, the figure and the ground can be reversed depending on what the attention window is focused to. However, as the former is limited by the time axis, the reversion is not possible, that is, an anacoluthon will always be the figure and the Comment will always be the ground.

\section{References}

BAUMANN, S. Information Structure and Prosody: Linguistic Categories for Spoken Language Annotation. In: SUDHOFF, S.; LENERTOVÁ, D.; MEYER, R.; PAPPERT, S.; AUGURZKY, P.; MLEINEK, I.; RICHTER, N.; SCHLIEßER, J. (eds.). Methods in Empirical Prosody Research. Berlin; New York: De Gruyter, 2006. p. 153-180.

BOCK, A.; FURTADO, O.; TEIXEIRA, M. Psicologias: uma introdução ao estudo da psicologia. São Paulo: Saraiva, 2001.

CAVALCANTE, F. The information unit of Topic: a crosslinguistic, statistical study based on spontaneous speech corpora. 2020. 191f. Dissertation (Doctorate in Linguistic Studies) Federal University of Minas Gerais, Belo Horizonte, 2020.

DePAPE, A.; CHEN, A.; HALL, G.; TRAINOR, L. Use of prosody and information structure in high functioning adults with autism in relation to language ability. Frontiers in Psychology, v. 3, n. 72, p. 1-13, 2012. 


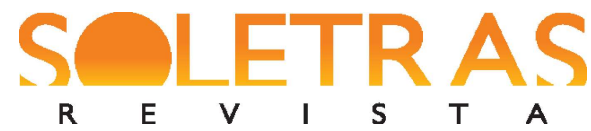

N. 41 - 2021.1 - LUIS FILIPE LIMA E SILVA

RONALDO RODRIGUES DE PAULA

DEROY, O. Modularity of Perception. In: MATTHEN, M. (ed.). The Oxford Handbook of Philosophy of Perception. New York: Oxford University Press, 2015. p. 756-780.

DEUTSCH, D. Musical Illusions and Phantom Words: How Music and Speech Unlock Mysteries of the Brain. New York: Oxford University Press, 2019.

DEVINSKY, O.; D'ESPOSITO, M. Neurology of cognitive and behavioral disorders. New York: Oxford University Press, 2004.

DUBOIS, J.; CHAFE, W.; MEYER, C.; THOMPSON, S.; ENGLEBRETSON, R.; MARTEY, N. Santa Barbara corpus of spoken American English. Parts 1-4. Philadelphia: Linguistic Data Consortium, 2000-2005.

FARAH, M. Visual Agnosia. $2^{\text {nd }}$ edition. Cambridge, London: The MIT Press, 2004.

FUKUI, R. The notions of figure and ground in linguistics and those in psychology. Acta Scientiarivm Valetvdinis Universitatis Praefectvralis Ibarakiensis, v. 19, p. 103-107, 2014.

GUT, U.; PILLAI, S. Prosodic marking of information structure by Malaysian speakers of English. Studies in Second Language Acquisition, v. 36, p. 283-302, 2014.

HARTMANN, G. Gestalt psychology and mathematical insight. The Mathematics Teacher, v. 59, n. 7, p. 656-661, 1966.

HASSON, U.; HENDLER, T.; BASHAT, D.; MALACH, R. Vase or Face? A Neural Correlate of Shape-Selective Grouping Processes in the Human Brain. Journal of Cognitive Neuroscience, v. 13, n. 6, p. 744-753, 2001.

HEDBERG, N.; SOSA, J. The Prosody of Topic and Focus in Spontaneous English Dialogue. In: LEE, C.; GORDON, M.; BÜRING, D. (eds.). Topic and Focus. Cross-linguistic Perspectives on Meaning and Intonation. Dordrecht: Springer, 2008. p. 101-120.

HERGENHAHN, B. An Introduction to the History of Psychology. $6^{\text {th }}$ edition. Belmont: Cengage Learning, 2009.

HIMMELMANN, N. Some preliminary observations on prosody and information structure in Austronesian languages of Indonesia and East Timor. In: RIESBERG, S.; SHIOHARA, A.; UTSUMI, A. (eds.). A cross-linguistic perspective on information structure in Austronesian languages. Berlin: Language Science Press, 2018.

KOFFKA, K. Principles of Gestalt Psychology. New York: Harcourt, Brace and Company, 1936[1935].

KÖHLER, W. Gestalt Psychology: An Introduction to New Concepts in Modern Psychology. New York: Liveright, 1992[1947]. 


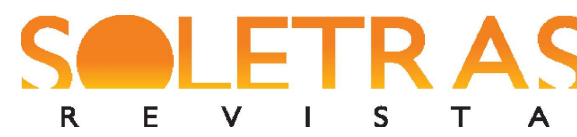

N. 41 - 2021.1 - LUIS FILIPE LIMA E SILVA

RONALDO RODRIGUES DE PAULA

KUMASHIRO, T.; LANGACKER, R. Double-Subject and Complex Predicate Constructions. Cognitive Linguistics, v. 14, p. 1-45, 2003.

LANGACKER, R. Foundations of Cognitive Grammar. Vol 1: Theoretical prerequisites. Stanford: Stanford University Press, 1987.

LANGACKER, R. Foundations of Cognitive Grammar. Vol 2: Descriptive Application. Stanford: Stanford University Press, 1991.

LANGACKER, R. Topic, Subject, and Possessor. In: SIMONSEN, H.; ENDRESEN, R. (eds.). A Cognitive Approach to the Verb: Morphological and Constructional Perspectives. Berlin; New York: Mouton de Gruyter, 2001. p. 11-48.

LANGACKER, R. Cognitive Grammar: A basic introduction. New York: Oxford University Press, 2008.

LANGACKER, R. Baseline and elaboration. Cognitive Linguistics, v. 27, p. 405-439, 2016.

LEZAMA, J.; BLUSSEAU, S.; MOREL, J.; RANDALL, G.; VON GIOI, R. Psychophysics, Gestalts and Games. In: CITTI, G.; SARTI, A. (eds.). Neuromathematics of Vision. Berlin: Springer, 2014. p. 217-242.

LI, C.; THOMPSON, S. Subject and topic: A new typology of language. In: LI, C. (ed.), Subject and topic. New York: Academic Press, 1976. p. 457-489.

LOY, G. Musimathics: The Mathematical Foundations of Music. Vol. 1. Cambridge, London: The MIT Press, 2006.

MELLO, H.; SILVA, L. F. L. Focus and information patterning: refining terminology and distinguishing categories in a spoken corpus. Revista Virtual de Estudos da Linguagem, v. 13, n. 10, p. 138-169, 2015.

MILLER, J.; WEINERT, R. Spontaneous Spoken Language. Oxford: Clarendon Press, 1998.

MORAES, J.; RILLIARD, A. Describing the intonation of speech acts in Brazilian Portuguese: Methodological aspects. In: FELDHAUSEN, I.; FLIESSBACH, J.; VANRELL, M. (eds.). Methods in prosody: A Romance language perspective. Berlin: Language Science Press, 2018. p. 229-262.

NICOLÁS MARTÍNEZ, C; LOMBÁN SOMACARRERA, M. Mini-Corpus del español para DB-IPIC. CHIMERA - Romance Corpora and Linguistic Studies, v. 5, n. 2, p. 95-113, 2018.

ROSS, J. Constraints on Variables in Syntax. 1967. 523f. Dissertation (Doctorate in Linguistics) - Massachusetts Institute of Technology, Cambridge, 1967.

RUBIN, E. Visuell wahrgenommene Figuren. Studien in psychologischer Analyse. Copenhagen: Gyldendal, 1921[1915]. 


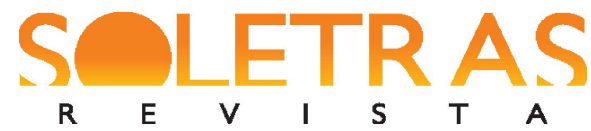

N. $41-2021.1$ - LUIS FILIPE LIMA E SILVA

RONALDO RODRIGUES DE PAULA

SAMARIN, W. Tongues of Men and Angels: The Religious Language of Pentecostalism. New York: Macmillan, 1972.

SARTAIN, J.; NORTH, J.; STRANGE, R.; CHAPMAN, M. Psychology: Understanding the Human Behavior. New York: McGraw-Hill, 1973.

SCHULTZ, D.; SCHULTZ, S. A History of Modern Psychology. $10^{\text {th }}$ edition. Belmont: Cengage Learning, 2011.

SILVA, L. F. L. Tipologia de construções clivadas de um corpus de língua oral espontânea. Working Papers em Linguística, v. 13, n. 3, p. 45-61, 2012.

SILVA, L. F. L. Sintaxe da fala, probabilidade e cognição: uma proposta integrada de investigação em estudo sobre NPs baseado em corpus. 2020a. 309f. Dissertation (Doctorate in Linguistic Studies) - Federal University of Minas Gerais, Belo Horizonte, 2020a.

SILVA, L. F. L. O estatuto da sintaxe na fala: considerações acerca da proposta da Language into Act Theory. Revista de Estudos da Linguagem, v. 28, n. 1, p. 271-330, 2020 b.

SILVA, L. F. L.; MELLO, H. The pragmatics of verbal negation in Brazilian Portuguese: Hypothesis testing with corpus data. Chimera: Romance Corpora and Linguistic Studies, v. 3, n. 2, p. 311-323, 2016 .

SILVA, L. F. L.; MELLO, H. Constraints on the usage of verbal negation in Brazilian Portuguese: Evidence from a spoken corpus. Káñina, v. 40, n. 1, p. $2016 \mathrm{~b}$.

SILVA, L. F. L.; MELLO, H. Predicate negation in spoken Brazilian Portuguese: Pragmatic analysis based on corpus data. In: DE MEO, A.; DOVETTO, F. (eds.). La comunicazione parlata/Spoken Communication. Roma: Aracne editrice, 2017. p. 375-391.

't HART, J.; COLLIER, R.; COHEN, A. A perceptual study on intonation: An experimental approach to speech melody. Cambridge: Cambridge University Press, 1990.

TALMY, L. Figure and ground in complex sentences. Proceedings of the First Annual Meeting of the Berkeley Linguistics Society, v. 1, p. 419-430, 1975.

TALMY, L. Toward a Cognitive Semantics. Vol. I/II. Cambridge: MIT Press, 2000.

TENNEY, J.; POLANSKY, L. Temporal Gestalt Perception in Music. Journal of Music Theory, v. 24, n. 2, p. 205-241, 1980.

WEITEN, W. Psychology: Themes and Variations. $10^{\text {th }}$ edition. Boston: Cengage Learning, 2017.

WOLDT, A.; TOMAN, S. (eds.). Gestalt Therapy: History, Theory, and Practice. Thousand Oaks: Sage Publications, 2005. 


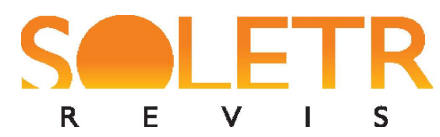

\title{
Caracterização de SNs sujeito e anacoluto em Tópico: uma abordagem baseada na Gramática Cognitiva e na Psicologia da Gestalt
}

\begin{abstract}
Resumo: Neste artigo, analisam-se SNs em Tópico que podem ser ou sujeitos do verbo do Comentário, ou itens autônomos, o que normalmente denomina-se anacoluto (LI; THOMPSON, 1976). Explora-se como esses diferentes SNs são mapeados de acordo com dados de fala espontânea. Partindo da proposta de Langacker (2001), na qual o Tópico e o sujeito atuam como trajetores de âmbitos distintos, argumenta-se que tal conceito é adequado aos dados empíricos, uma vez que permite a possibilidade de co-ocorrência e de entrelaçamento de ambas categorias no discurso oral. Além disso, com base nos conceitos de baseline e elaboration (LANGACKER, 2016), explora-se a diferença no processamento cognitivo de SNs sujeitos e anacolutos quando eles figuram em Tópico. Considera-se, dentro dessa perspectiva, que a articulção Tópico-Comentário é ativada serialmente podendo resultar na formação de camadas estrutuais, caso os SNs em Tópico sejam sujeito do verbo no Comentário, bem como pode resultar num acesso cumulativo via soma, caso os SNs sejam anacolutos. Como os conceitos de sujeito e Tópico na abordagem da Gramática Cognitiva derivam, em parte, das noções de Figura e Fundo da psicologia da Gestalt, o anacoluto em Tópico pode-se referir como a Figura, e a força ilocucionária do Comentário seria o Fundo. A única diferença em relação aos elementos visuais é que, como eles configuram-se através do espaço, a figura e o fundo podem ser invertidos dependendo para onde o foco de atenção está voltado. Porém, como o fala se desdobra pelo eixo do tempo, a reversão não é possível, de tal sorte que um anacoluto em Tópico será sempre a figura e o Comentário sempre será o fundo. Além disso, a dependência da figura a um fundo explicaria por que um Tópico não pode ocorrer sem estar relacionado a um Comentário.
\end{abstract}

Palavras-chave: Sintagma Nominal. Sujeito. Anacoluto. Tópico. Gestalt.

Recebido em: 17 de setembro de 2020.

Aceito em: 16 de dezembro de 2020. 